\title{
The Impact of Technological Development on Jordanian Industrial Sector
}

\author{
Mahmoud F. AL-Refai ${ }^{1}$, Samer Abdelhadi ${ }^{1}$ \& Adli A. Al-Qaraein ${ }^{2}$ \\ ${ }^{1}$ Department of Finance and Banking, Faculty of Administrative and Financial Sciences, University of Petra, \\ Jordan \\ ${ }^{2}$ Department of Finance, Faculty of Business, The University of Jordan, Jordan \\ Correspondence: Mahmoud F. AL-Refai, Department of Finance and Banking, Faculty of Administrative and \\ Financial Sciences, University of Petra, Jordan. E-mail: mrefai@uop.edu.jo
}

Received: February 4, 2016

Accepted: March 2, 2016

Online Published: March 15, 2016

doi:10.5539/ijbm.v11n4p291

URL: http://dx.doi.org/10.5539/ijbm.v11n4p291

\begin{abstract}
The technological advancement being considered as an essential core of economic development, whereby the introduction of new technology will not only reduce production costs, but could also lead to increasing the efficiency of production processes. Jordan is one of those countries that had made substantial progress in implementing new technology in various sectors, which reflected in a positive way on the Jordanian economy. This study aims to identify the effects of technological development on the industrial sector in Jordan during the period (1990-2014), and its role in the development and increase in the volume of industrial production in order to achieve self-sufficiency and providing job opportunities for the unemployed. The analysis used the method of Vector Error Correction Model (VECM) in estimating a function of the Cobb Douglas production. The study concluded that technology has a positive impact on the industrial sector in Jordan, and that the technological capital should be more intensive in the long term.
\end{abstract}

Keywords: technology, Jordanian industrial sector, Cobb Douglas, vector error correction model (VECM)

\section{Introduction}

The word technology is a Greek word originally composed of two segments. The first is (Techno) which means art or skill, and the second is (Logy), which means science or study. The concept of technological development differs from one economist to another. While (Mansfield, 1982) defined technological development as the application of new techniques in marketing, production, management and administration, (Solow, 1956) considered technological development in the economic growth model as an external variable which, affects economic growth in the long run. The Solow model, after the addition of a changing technology, was called "Exogenous Growth Model".

The technological progress was an essential element in economic development, where the introduction of new technology generally leads to reduced production costs and increase in the efficiency of the manufacturing processes. The technological progress could create new opportunities in other sectors, and expand the supply and demand in the industries where technology was previously non-existent as well as provide the means for establishing standards of quality and allow for a developing country to build credibility in the global market. All of this will be reflected in a positive way on the economy, as emphasized by the World Bank that "the understanding of how the emergence of goods and services can be produced, is one of the critical factors in achieving economic progress".

The technological development is related to the development process, where a comprehensive change in various aspects of the economic and social life needs an accumulation of knowledge and scientific progress to achieve a better quality of life and economic welfare (Mohamed, 2007). The importance and accumulation of knowledge comes mainly from additional spending on scientific research and development (R\&D). The proportion of spending on research and development in developing countries was only $0.5 \%$ of GDP compared with $2.5 \%$ in developed countries.

Therefore, we should encourage scientific research institutions to intensify research, which in turn will contribute to the achievement of technological development in developing countries, but must take into account 
that any new technology is geared towards the labor intensive economy rather than capital intensive, because most of the developing countries feature abundant labor component.

The developing countries experienced in recent times an unprecedented level of technological progress, particularly in the areas of foreign trade and investment in human capital. In fact, the technological achievement in the low and medium income countries was faster than in high income countries. In spite of this huge growth, there remains a large gap in the technological aspect between developing and developed countries, because the developing world is still in the early stages of the adopting existing technologies, rather than seek new innovations. In addition, although there is a diffusion of new technologies between countries, it takes longer to disseminate within developing countries. It is particularly important for governments to consider investment in modern technology to facilitate the inclusion of their country in the world economy.

Jordan is one of those states that had made progress in technology implementation in the various sectors which had a positive impact on the Jordanian economy as a whole. However, a more detailed study on the impact of technology on specific sectors is of high importance. Therefore, the objective of this study is to demonstrate the impact of technological development on the Jordanian industrial sector which is the back bone of the economy during the period 1990-2014.

The importance of this study stems from our belief that technological progress and implementation will help in increasing the volume of industrial product, and resolve many of the economic and poverty problems and will eventually help alleviate the deficit in the balance of trade, as well as achieve higher efficiency in production and its positive effects on economic growth rates in Jordan.

The rest of the paper is organized as follows: Section II provides an overview of the technological development in Jordan. Section III presents and overview of the literature on importance of technology in economic development and section IV describes the data and the methodology used; Section V discusses the empirical results while section VI concludes the study and offers recommendations.

\section{Technological Development in Jordan}

The global economic development which occurred in the past years led to the fusion of the world economies both developed and developing in which modern economic globalization was the catalyst. This led developed countries in their attempt to maintain the economic activity level to increase research and development in order to improve the methods of production and to increase economic growth and therefore improve the standard of living of their peoples. The extent to which they achieved this objective remains however questionable. On the other hand, developing countries continued to strive to get out of the first stage of the development process and incrementally transit to the ranks of the developed countries.

The technological gap attributed by some, as one of the consequences of economic globalization, led to the widening of the gap between the economic and social aspects of developing and developed countries. This gap was referred to as "the mother gap" as a connotation for the prevailing difference between different economies. (Hijazi, 2005)

Jordan, like other developing countries, is suffering from the presence of this technological gap, in spite of the continuous attempts to reduce it. The method used to measure the technological gap in the economy is the Growth Competitiveness Index (GCI), because it has many indicators relating to macroeconomic condition, where this reflects the cursor over the capacity of the country to achieve sustained economic growth in the medium term. Moreover, it is used as a tool available to decision makers in their effort to guide the economic policies of their countries at both the macro and micro levels in order to raise the competitiveness of their economies, as well as to enhance the ability of businessmen and investors in directing their investments towards the optimal uses (Abdelhadi, 2010). The calculations take into consideration the following index factors:

1. The technology index: it reflects the evolution of technology in countries through the following sub factors: innovation index, the communications and information technology, and the transfer of technology.

2. The public institutions index: where this reflects the extent to which public institutions have developed through the following sub factors: contracts and laws index and corruption index.

3. Index of business environment at the macroeconomic level which reflects the development of this environment on the basis of the following indicators: macroeconomic stability, the credit classification and government expenditures index.

The figures of this index have been mentioned in a report issued by the World Economic Forum in Davos-Switzerland. The first appearance of Jordan in this report was in 1996. It is worth mentioning that the 
Competitiveness Unit in the Jordanian Ministry of Planning, which was established in 1997, has the responsibility to follow-up on this report especially with regard to the performance and progress of the Jordanian economy and to compare it with economic progress of other countries both developed and developing. (World economic forum reports).

In 1996 Jordan was ranked 28 which inspired the Jordanian government to make a greater effort to reach an advanced ranking level among other countries. Jordan has achieved progress in 2003 where it was ranked 34 out of 102 countries, then retreated according to this indicator where it was ranked 52 in 2006. (World economic forum reports).

The annual survey of the World Economic Forum in 2014 showed that Jordan progressed forward by 4 degrees in indicators of competitiveness to be ranked 64 globally and the eighth among Arab countries. The Global Competitiveness Report in 2014 which specializes in the competitive assessment of 144 countries showed relative improvement in the economic indicators of the kingdom in terms of reducing the budget deficit and the developments in the areas of education and financial market. The assessment of the forum is based on competitiveness on several factors, the most prominent of which is the institutional framework and infrastructure, health and education, the size of the market, environment at the macroeconomic level, development of capital markets, availability of technology, and of business development and creativity. The report takes into account the views of business people on the extent to which the government efficient and transparent. (World economic forum reports)

In general, we can say through statistics, that Jordan is moving steadily toward the achievement of advanced ranking in all indicators that are used in the assessment of the country and assigning the proper ranking according to the competitive index growth, which in turn will work to bridge the technological gap between Jordan and the developed countries.

\section{Literature Review}

There are some important contributions in the 1960s of the last century by some economists on technological development. (Arrow, 1962) found that technological development grew steadily over time and that economic growth in the long term depends mainly on population growth.

Uzawa (1965), Phelps (1966), Conlisk (1967) and Shell (1967) found that technological growth is based mainly on the human resources ability to continue to develop the technology through the creativity and innovation.

Vernon (1966) pointed out through the theory of the product cycle, the reasons for the establishment of a foreign trade between countries is that the possession of technology by one of the countries over the other and which draws its presence from innovative capabilities.

As pointed out by Romer (1990), Grossman and Helpman (1991) and Aghion and Howitt (1992), they agreed that more spending on the development of technology will lead in the end to the achievement of further economic growth.

Jones (1995) gave several explanations for the contrasting relationship between the state of technology and productivity growth, known in literature as the productivity paradox.

Loo and Soete (1999) concluded that the notion that R\&D efforts are more and more attributed to product differentiation, thus enlarging consumers' welfare while simultaneously exhibiting only limited effects on economic growth, looks very promising in explaining the productivity paradox.

Gurbiel (2002) found that most of Central and Eastern Europe countries experienced large GDP declines in the 1990 's which was resulted to a large extent from an overall decline in competitiveness and increasing technology gap in comparison to western countries.

Schlicht (2015) explained that the hybrid model so obtained explains balanced growth in a way that appears less arbitrary than other possible explanations in the Solow model, especially because it directly accounts for Harrod neutral technical change, without any need for further assumptions. It complements the current neoclassical and AK models by offering a further perspective for interpreting economic growth.

\section{Data and Methodology}

Based on the above reviews and consensus on theories about the relationship between technological development and the overall sectors' economic growth, it is important to indicate that the impact of technological development and the size of the labor \& capital accumulation as independent variables and the industrial growth as a dependent variable. 
We will adopt the theoretical and descriptive approach to determine the relationship between technological development and industrial growth in Jordan. In addition, there will be a review of opinions of some economists about the nature of this relationship. We will also use the quantitative method for some of the tests, such as Unit Root Test, Co-integration, and the Vector Error Correction Model (VECM) in estimating the Cobb Douglas production function. The research will also rely on the data from several sources such as Central Bank of Jordan, Department of Statistics, and the World Economic Forum.

The study is based on the null hypothesis that "there is no impact of the technological development on industrial growth in Jordan".

After describing the relationship between technological development and industrial growth in theory, a practical analysis of this relationship will be conducted in an effort to strengthen the theoretical side and to achieve the goals of the study. In particular, the main objective of this part is the standard analysis of the impact of technological development on industrial growth in Jordan during the period 1990-2014 by using the Cobb Douglas function.

\section{A. Estimating the Production Function}

The production function indicates the maximum amount of production that can be obtained by using a combination of certain factors of production at a certain level of technology. The production function has many characteristics as it is a homogeneous function which assumes the achievement of technical competence in production and an addition of any productive factor would lead to an increase in total production, i.e. the marginal productivity of factors of production are positive, and the marginal productivity of each factor of production decreases with the increase of this factor (Henderson \& Quandt, 1980).

The Cobb Douglas production function will be estimated and subsequently, the size of the technological development will be identified according to the following equation whereby industrial production is a function of labor, capital and time:

$$
Q=f(L, K, T)
$$

The time factor measures the impact of Disembodied Technological Change, which is intended to proceed in the productive process over time, regardless of the change in production input through education, training and management (Hammuri, 1999). The impact of technological change can be traced in several ways among which are the technical efficiency and the change through the residuals and return to scale (Mohamed, 2007).

\section{B. Technical Efficiency}

Technical efficiency is defined as the maximum amount of goods and services produced by using the available economic resources and at the lowest cost, as in Equation 2.

$$
Q=T L^{\alpha} K^{\beta}
$$

Where:

Q: Industrial Production Quantity.

T: Technological development.

L: Number of Labor Employed in Industrial Sector.

K: Gross Fixed Capital Formation.

$\alpha, \beta$ : elasticity of Industrial Production for labor and capital, respectively.

\section{Measure Technological Change through the Residuals}

Where technological change is indicated by the change in real output minus the change in both labor and the accumulation of capital and so the remainder is the amount of technological change, as in Equation 3

$$
\Delta T=\Delta Q-\alpha \Delta L-\beta \Delta K
$$

\section{Return on Scale}

It refers to the change in output resulting from a change in one or more of the production factors; If the value of $(\alpha+\beta)$ is greater than one, it means that production is in a state of increasing return to scale, but if the value $(\alpha+$ $\beta$ ) is less than one, it means that production is in a decreasing state of return to scale, and if the value of $(\alpha+\beta)$ is equal to the one, it means that production is in a constant state of return to scale.

To estimate the parameters $(\alpha, \beta, T)$, we will take the logarithm of equation (2) as in Equation 4 below.

$$
\log Q=\log T+\alpha \log L+\beta \log K+e
$$


Equation (4) can be estimated through the Ordinary Least Squares method (OLS), assuming that random errors are distributed normally, with a mean equal to zero and constant variance, and that there is no correlation between random errors values as well as there is no correlation between the explanatory variables among themselves and between them and the random error term. The time series must be stationary; the mean variance and covariance are constant over time. In the absence of any one of these conditions, the data will not be stationary, and in this case, the estimate model parameters by least squares method will not be appropriate and may be indicative of a spurious regression. Furthermore, if at least one of these explanatory variables is non stationary, the general trend will appear in the equation and the explanatory variables will be non-stationary and statistically insignificant. Consequently, the coefficient of determination (R2) value will be high, and the result would be misleading and unrealistic. Therefore, we should apply the unit root test and Granger Causality Test, as well as the co-integration test on the time-series variables of the study.

\section{Empirical Results}

\section{A. Unit Root Test}

Unit root test is the first step that should be done to ascertain that the time-series are stationary; stationary at the level and be in this case an integrated of degree zero $\mathrm{I}(0)$, or stationary at first differential; integrated of degree one I(1), or stationary at the second differential; integrated of degree two I(2) and so on. The Augmented Dickey Fuller test has been used and Table (1) below, summarizes the test results:

Table 1. Unit root test results (ADF)

\begin{tabular}{|c|c|c|c|c|}
\hline Variables & Test & Level & 1st difference & integrated \\
\hline \multirow{4}{*}{ Ln (Q) } & ADF Statistic & -1.28 & -6.11 & \multirow{4}{*}{$\mathrm{I}(1)$} \\
\hline & $1 \%$ & -3.74 & -3.75 & \\
\hline & $5 \%$ & -2.99 & -2.99 & \\
\hline & $10 \%$ & -2.64 & -2.64 & \\
\hline \multirow[t]{4}{*}{$\operatorname{Ln}(\mathrm{K})$} & ADF Statistic & -0.71 & -10.34 & \multirow{4}{*}{$\mathrm{I}(1)$} \\
\hline & $1 \%$ & -3.74 & -3.75 & \\
\hline & $5 \%$ & -2.99 & -2.99 & \\
\hline & $10 \%$ & -2.64 & -2.64 & \\
\hline \multirow[t]{4}{*}{$\operatorname{Ln}(\mathrm{L})$} & ADF Statistic & -1.14 & -5.78 & \multirow{4}{*}{$\mathrm{I}(1)$} \\
\hline & $1 \%$ & -3.74 & -3.75 & \\
\hline & $5 \%$ & -2.99 & -2.99 & \\
\hline & $10 \%$ & -2.64 & -2.64 & \\
\hline
\end{tabular}

The results indicate that the calculated values of $\operatorname{Ln}(\mathrm{Q})$, $\mathrm{Ln}(\mathrm{K})$, and $\mathrm{Ln}(\mathrm{L})$ were less than the critical values at the level which means that these variables are not stationary at the level. However, the variables, $\mathrm{Ln}(\mathrm{Q}), \mathrm{Ln}(\mathrm{K})$, and $\mathrm{Ln}(\mathrm{L})$ have become stationary when it was used at the first differential where the calculated values were greater than the critical values; it has become integrated of degree one I(1) at $1 \%$ significance level.

\section{B. Granger Causality Test}

The causality test is used to determine the direction of the relationship between economic variables, and to verify the direction of the relationship between the variables of time-series models (Gujarati, 2003).

Table 2. Granger causality test results

\begin{tabular}{llll}
\hline Null Hypothesis: & Observations & F-Statistic & Prob. \\
\hline Ln_K does not Granger Cause Ln_Q & 25 & 5.254 & 0.033 \\
Ln_Q does not Granger Cause Ln_K & 25 & 0.542 & 0.927 \\
Ln_L does not Granger Cause Ln_Q & 25 & 4.319 & 0.036 \\
Ln_Q does not Granger Cause Ln_L & 25 & 0.239 & 0.862 \\
Ln_L does not Granger Cause Ln_K & 25 & 1.559 & 0.229 \\
Ln_K does not Granger Cause Ln_L & 25 & 1.006 & 0.380 \\
\hline
\end{tabular}


The results in Table 2 indicate that:

1. The null hypothesis is rejected with a level of significance of $5 \%$, which suggests that " $K$ " helps explain changes in (Q) where the statistical (F) was 5.25 at a probability of 0.033 .

2. The null hypothesis is rejected which suggests that "L" helps explain changes in $(\mathrm{Q})$ which amounted to a statistical (F) 4.32 with a probability of 0.036 .

\section{VAR Lag Selection Criteria}

We use this test to figure out the most suitable estimation of the period of time, and by means of the results presented in Table 3, and based on the Schwarz information criterion, it became evident that Lag (6) is the most appropriate for the estimation process.

Table 3. VAR lag order selection criteria

\begin{tabular}{lccllll}
\hline Lag & LogL & LR & FPE & AIC & SC & HQ \\
\hline 0 & 28.66 & NA & $1.35 \mathrm{e}$ & -2.70 & -2.55 & -2.78 \\
1 & 75.68 & $74.24^{*}$ & $2.51 \mathrm{e}$ & -6.71 & -6.11 & -6.60 \\
2 & 85.92 & 12.93 & $2.41 \mathrm{e}$ & -6.63 & -5.79 & -6.66 \\
3 & 96.66 & 10.18 & $2.56 \mathrm{e}$ & -7.02 & -5.53 & -6.76 \\
4 & 108.45 & 7.45 & $3.36 \mathrm{e}$ & -7.31 & -5.37 & -6.98 \\
5 & 142.57 & 10.78 & $9.68 \mathrm{e}^{*}$ & -9.96 & -7.57 & -9.55 \\
6 & 1312.87 & 0.00 & NA & $-32.19^{*}$ & $-29.36^{*}$ & $-31.72^{*}$ \\
\hline
\end{tabular}

* indicates lag order selected by the criterion.

LR: sequential modified LR test statistic (each test at $5 \%$ level).

FPE: Final prediction error.

AIC: Akaike information criterion.

SC: Schwarz information criterion.

HQ: Hannan-Quinn information criterion.

\section{Co-Integration Test}

According to the Co- integration test of the variables, the results presented in Table 4 show that there is two complementary vector at a significance level of $5 \%$. In other words, Trace test indicates two co-integrating at the 0.05 level. This means accepting the alternative hypothesis $r=2$ and rejecting the null hypothesis $r=0$, where $r$ denotes the number of integrative vectors.

Table 4. Co-integration test

\begin{tabular}{lcccc}
\hline Hypothesized No. of CE(s) & Eigenvalue & Trace Statistic & 0.05 Critical Value & Prob.** \\
\hline None $*$ & 0.507 & 31.507 & 29.797 & 0.0315 \\
At most 1 & 0.486 & 15.956 & 15.495 & 0.0424 \\
At most $2 *$ & 0.058 & 1.318 & 3.841 & 0.2509 \\
\hline
\end{tabular}

Trace test indicates 1 cointegrating eqn(s) at the 0.05 level

* denotes rejection of the hypothesis at the 0.05 level

**MacKinnon-Haug-Michelis (1999) p-values

Whenever there is co- integration among variables in the model, we can use Vector Error Correction Model (VECM), to estimate the economic functions. Table 5 shows that there is a long-term relationship whereby a one unit change in capital will positively affect industrial output by 0.43 . This effect is statistically significant as the value of $t$ calculated is 5.32 is greater than critical value at $5 \%$ level of significance. Moreover, if labor changes by one unit, it will positively impact industrial output by 2.74 , and this effect is statistically significant as the value of $\mathrm{t}$ calculated is 3.94 is greater than the critical value at the level of significance of $5 \%$. We also found that the value of the constant, which represents technological change, has a positive impact on production to the magnitude of 27.50 . 
Table 5. Vector error correction estimates

\begin{tabular}{lc}
\hline Cointegrating Eq: & CointEq1 \\
\hline LOG $(\mathrm{Q}(-1))$ & 1.000000 \\
LOG(K(-1)) & 0.431037 \\
& $(0.08107)$ \\
LOG(L(-1)) & $-5.31689]$ \\
& -2.740451 \\
C & $(0.69602)$ \\
\hline R-squared & {$[-3.93732]$} \\
Adj. R-squared & 27.50237 \\
Sum sq. resids & 0.680 \\
F-statistic & 0.548 \\
\hline
\end{tabular}

The results also indicate that the production works at phases of increasing economic returns in the long-term, whereby the $(\alpha+\beta>1)$ which is 3.17. The value $(\beta / \alpha)$ was 0.16 , while the value of $(\alpha / \beta)$ is 6.36 . This shows that technological change is more labor intensive in the long term. The technology effect appears by constant, which has a positive effect on industrial output.

The value of the adjusted coefficient of determination $\left(R^{2}\right)$ amounted to almost 0.68 , which means that $68 \%$ of the variation in production can be explained by the independent variables (labor, capital, and time), and the F value higher than critical value which suggests the appropriateness of the model as a whole.

Accordingly the Cobb Douglas estimate becomes a function in the long term, according to previous findings, as in Equation (5):

$$
\text { Ln } Q=2.740451 \operatorname{Ln} L+0.431037 \operatorname{Ln} K+27.50237
$$

\section{Conclusion and Recommendation}

This study aims to identify the effects of technological development on the industrial sector in Jordan during the period (1990-2014). We conclude from this study that Jordan is progressing steadily towards advanced positions in all indicators that go into assessing the state and give it a good rank according to the growth competitiveness index. This in turn will serve to narrow the technological gap between Jordan and the developed countries. The results indicate that production works in increasing the economic returns in the long-term as the $(\alpha+\beta>1)$. Technological change has a positive impact on production, and this means rejecting the null hypothesis of the study, which states that there is no positive impact of technological development on economic growth in Jordan which is compatible with the opinion of Vernon (1966). According to the statistical results, technological change is more capital intensive in the long term which is agreed with Romer (1990), Grossman and Helpman (1991) and Aghion and Howitt (1992).

Based on the above results, this study reached to so recommendations. The government should be placed the capital element especially in the long term because of its positive impact on economic growth in Jordan. The economy should emphasis on the development and training of the labor force in order to be more qualified in order to be able to make a positive impact on economic growth in Jordan in the long run. And, conducting additional studies on technological development and its impact on the competitiveness of the economic sectors in Jordan, the most important of which is the industrial, agricultural and services sector, which constitute the largest portion of the real GDP.

\section{References}

Abdelhadi, S. (2010). External funding and its Impact on Economic Gaps: the Case of Jordan for the period (1990-2009). Published PhD Thesis, Dar AL-Ayam for publication, Amman, Jordan

Aghion, P., \& Howitt, P. (1992). A Model of Growth through Creative Destruction. Econometrica, 60(2), 323-351. http://dx.doi.org/10.2307/2951599

Arrow, K. (1962). The Economic Implications of Learning by Doing. The Review of Economic Studies, 29(3), 155-173. http://dx.doi.org/10.2307/2295952

Central Bank of Jordan. (n.d.). Central Bank of Jordan. Annual Reports. Amman, Jordan. 
Conlisk, J. (1967). A Modified Neoclassical Growth Model with Endogenous Technical Change. Southern Economic Journal, 34(2), 199-208. http://dx.doi.org/10.2307/1055037

Department of Statistics. (n.d.). Department of Statistics. Annual Reports. Amman, Jordan.

Grossman, G., \& Helpman, E. (1991). Innovation and Growth in the Global Economy. Cambridge: MIT Press.

Gujarati, D. (2003). Basic Econometrics (4th ed.). New York: McGraw Hell.

Gurbiel, R. (2002). Impact of Innovation and Technology Transfer on Economic Growth: the Central and Eastern Europe Experience. Working Paper.

Hamuri, N. (1999). Estimating Function Production Sector to Finance, Insurance, Real Estate and Business Services in Jordan. Master Unpublished. Yarmouk University, Irbid, Jordan.

Henderson, J., M., \& Quandt, R. E. (1980). Microeconomic Theory: A Mathematical Approach (3rd ed.). New York: Mc Grow-Hill.

Hijazi, N., \& Ali, N. (2005). The Digital Divide: An Arab Vision for the Knowledge Society. Series Knowledge World, Kuwait.

Jones, C. I. (1995). Time Series Tests of Endogenous Growth Models. Quarterly Journal of Economics, 110, 495-525. http://dx.doi.org/10.2307/2118448

Loo, I. D., \& Soete, L. (1999). The Impact of Technology on Economic Growth: Some New Ideas and Empirical Considerations. Working paper.

Mansfield, E. (1982). Microeconomics: Theory and Applications.

Mohamed, S. A. (2007). The Impact of Technological Development on the Industrial Sector Output in Iraq for the period 1970-1990. Technical Journal, 20(2).

Phelps, E. S. (1966). Models of Technical Progress and the Golden Rule of Research. Review of Economic Studies, 33(2), 133-145. http://dx.doi.org/10.2307/2974437

Romer, P. (1990). Growth Based on Increasing Returns Due to Specialization. The American Economic Review, 77(2), 56-62.

Schlicht, E. (2015). Directed Technical Change and Capital Deepening: A Reconsideration of Kaldor's Technical Progress Function.

Shell, K. (1967). A Model of Inventive Activity and Capital Accumulation. In K. Shell (Ed.), Essays on the Theory of Optimal Economic Growth. Cambridge, Massachusetts: MIT Press.

Solow, R. (1956). A Contribution to the Theory of Economic Growth. The Quarterly Journal of Economics, 70(1), 65-94. http://dx.doi.org/10.2307/1884513

Uzawa, H. (1965). Optimum Technical Change in an Aggregate Model of Economic Growth. International Economic Review, 6(1), 18-31. http://dx.doi.org/10.2307/2525621

Vernon, R. (1966). International Investment and International Trade in Product Cycle. In P. Buckley (Ed.), Internalization of the Firm. London: Academic Press. http://dx.doi.org/10.1002/tie.5060080409

World economic forum (n.d.). The Global Competitiveness Report. Retrieved from http://reports.weforum.org/

World economic forum. (n.d.). World economic forum, Annual survey of the world economic forum. Retrieved from http://www.weforum.org/reports

\section{Copyrights}

Copyright for this article is retained by the author(s), with first publication rights granted to the journal.

This is an open-access article distributed under the terms and conditions of the Creative Commons Attribution license (http://creativecommons.org/licenses/by/3.0/). 